\title{
Bank Size, Functional Distance and Loss Given Default Rate of Bank Loans
}

\author{
Matteo Cotugno (Corresponding Author) \\ University of Bologna, Department of Management \\ Via Capo di Lucca, 34, 40126, Bologna, Italy \\ Tel: +39-05-1209-8080Ｅ-mail: m.cotugno@unibo.it \\ Valeria Stefanelli \\ University of Rome "Nicolò Cusano", Department of Economics \\ Via Casalmonferrato, 2/b, 00182, Rome, Italy \\ Tel: +39-06-7030-7312_E-mail: valeria.stefanelli@unisu.it
}

Received: Febuary 4, $2011 \quad$ Accepted: March 2, $2011 \quad$ doi:10.5430/ijfr.v2n1p31

\begin{abstract}
Most of the studies available on relationship lending focuses on the benefits for borrowers and neglects those achievable for banks. In particular, empirical studies on the benefits achieved for banks in terms of loans recovery rate, in connection with loss given default rate, are very few. In contrast, choosing the best approach to managing loans is crucial in the current credit market considering the high deterioration in quality of bank loans.

This paper empirically tests whether the banks more oriented towards a relationship lending approach report a lower level of loss given default. Bank size and functional distance are used to measure the relationship lending approach in banks.

This paper takes into account the Italian banking system and the effectiveness of their debt recovery processes during the 2005-2008 period. The data has been collected by ABI Banking Data and Bank of Italy. The empirical analysis highlights that banks more oriented in the relationship lending model have a greater capacity to recover bad loans. These findings have some managerial implications.
\end{abstract}

Keywords: Loss given default, Relationship lending, Bank size, Functional distance

\section{Introduction}

Recently, academics and practitioners focus on best practices on lending technology useful to better monitoring and contrast the deterioration of the quality of banks loan portfolios. Choosing the best approach in credit relationship becomes, in fact, strategically relevant for banks also due to the recent international financial crisis.

In literature, most of the studies investigate the benefits of the lending technology for the borrower (Peterson and Rajan, 1994; Berger and Udell, 1995, Berger and Black, 2010), while studies relating to the advantages for the bank, in particular, in terms of improvement of the loss given default rate, are still few and conflicting.

The aim of this study is to empirically verify whether the banks more oriented towards a relationship lending approach report a lower level of loss given default.

The originality of this analysis is linked to both the nature of the relation investigated and to the measurements adopted, such as intensity proxies of bank relationship lending. In fact, the bank to customer geographical proximity element, essential in competitive organizations based on the value of the relation, is adopted in the analysis to identify any possible improvements in the quality of lending descending from the local market served.

In theory, the loss given default rate depends on three main factors: the characteristics of the lending relationship and the implicit components of the contract (collaterals); the effectiveness of the banking structure deputy to loans recovery; macroeconomic factors. Focusing only on the first aspect, the link existing between loss given default rate has been analyzed only in a few works (inter alia, Mattarocci and Gibilaro, 2009). Asarnow and Marker (1995) underline how the time factor in corporate bankruptcy is a crucial factor for the management of LGDR. Thanks to soft information, a close 
relationship allows the reduction of the time lag between the state's difficulties and the crisis has occurred. The bank is more effective in its monitoring process and economic advantages in the management of soft information (Cosci and Mattesini, 1997). The customer is also less likely to fail to honor its debts because it is difficult to replace the bank (Berger and Udell, 1995).

Despite the existence of an extensive literature on this topic, empirical tests that clearly link the relationship lending approach to the bank ability to improve the recovery of portfolio loans are almost non-existents. The probability of default in literature, in fact, has been analyzed in many studies, while empirical evidence on loss given default emerged only recently (Bastos, 2010). This paper assesses whether any benefits, in terms of the improvement of the LGD rate, are associated with a relationship-based lending technology.

The paper is structured in the following way: section 2 describes the literature and research hypotheses, section 3 describes the analysis sample and data used, section 4 illustrates the econometric model and related variables, while section 5 sets out the results of the empirical analysis. Finally, section 6 reports the conclusions.

\section{Literature review and research hypotheses}

Relationship lending can be understood as a technology based on the development of a privileged, collaborative and repeated lending relationship with the firm, in respect of which the bank invests in the collection of private information (soft information), thus qualifying as a financial partner of reference, with the objective of maximizing the profitability of the overall relation in the medium and long term (Sharpe, 1990; Stein, 2002; Boot, 2000; Berger et al., 2002; Scott, 2004). In theory, this approach is in contrast to the transactional one, which is characterized, instead, by a bank-customer relationship oriented to selling and maximizing the profits of market transactions, whose risk/return profile is generally estimated by the intermediary based on corporate accounting information and that found in the public domain (hard information) (Note 1).

There is a particularly broad literature on relationship lending, predominantly focusing on the benefits of relationship lending to enterprises expressed in terms of: explicit lending terms and conditions (Peterson and Rajan, 1994; Berger and Udell, 1995), loan availability (Peterson and Rajan, 1994; Cole, 1998), implicit components of the contract (request for collateral/personal guarantees) (Berger and Udell, 1995; Brick and Palia, 2007), anti-cyclical lending function (amongst others, Ferri and Messori, 2000).

The LGDR therefore is influenced by the type of relationship established with the customers, because a strong relationship enables banks to minimize valuation errors, with respect to the customers' investment projects, also by reducing the information asymmetries. In terms of organizational structure, the available literature seems to agree that small-sized banks can generally establish more lasting relationships, especially with smaller enterprises (Nakamura, 1993a; Nakamura, 1993b; MacNulty, 2001; Berger et al., 2002; Bonaccorsi di Patti et al., 2005). Thanks to customer proximity, to a widespread presence in local markets often characterized by a lower competitive emphasis, to frequent exchanges of information and high social interaction between the loan officer and the customers served, small banks have a competitive advantage to manage firms with greater information opacity.

Gibilaro and Mattarocci (2009) demonstrate that Cooperative Banks in Italy have a better recovery rate than system-wide, and the academic literature usually agrees on the fact that cooperative banks are the most suitable for implementing long-term relationships. A recent empirical analysis by Berger and Black (2010) questioned the current research paradigm: large banks do not have equal advantages in all the hard lending technology described in literature, nevertheless it confirms that small banks have a comparative advantage in relationship lending and especially with respect to larger companies.

Smaller banks are also more efficient in respect of the customer monitoring process, and the closer relationship enables them to handle any difficult situations affecting an enterprise, restructuring the debt, if necessary, before the value of its assets is entirely destroyed (Cosci and Mattesini, 1997).

Having regard to the borrower profile a part of the literature highlights a negative relationship between LGDR and relationship lending. Given the strong relationship, in fact, it is highly unlikely that the borrower fails to honor its debt, because otherwise it would be very difficult to find other banks willing to grant loans at the same conditions (Berger and Udell, 1995). Moreover, valuation errors are less frequent by the banks, thanks to the limited amount of information asymmetries resulting from a long-lasting relationship (Longhofer and Santos, 1999).

In this perspective, the literature concludes that the best organizational form for the lending relationship is, effectively, that of small banks, where fewer hierarchy levels exist and, therefore, fewer problems regarding the control of the organizational processes and the behavior of the personnel involved in the lending activities. Therefore, we can associate a greater propensity toward lending technology with bank size. It follows that, in small banks, and particularly in 
community banks, there is a minimal distance between the customer manager (who collects information on the customers) and the loan officer (who instead is responsible for the making loan decisions); in theory, this characteristic should facilitate the collection of soft information in small organizations (De Young, 2004).

Berger and Udell (2002) argue that in order for banks to fully exploit soft information the loan officers must have ample decision-making margins in respect of customer relations management, offset by an adequate system of checks aimed at minimizing traditional agency problems.

In light of these considerations, the following hypothesis is formulated:

Hp1: the loss given default rate positively depends on the size of the bank (bank size).

Aside from the structural aspects, subsequent studies explored the features of a bank's internal organization, in order to establish in greater detail the propensity to relationship lending expressed in the core business. In particular, in the face of the intense consolidation and restructuring process that the banking system has been involved in the last ten years, recent analyses (Zazzaro, 2006; Alessandrini et al., 2009) record among the effects of this process a progressive increase in the functional distance of banks, or rather, the distance between the headquarters where the loan officer evaluates creditworthiness, and the branches scattered throughout the market. The hypothesis of functional distance is based on the argument that a wider distance between the headquarters and the various branches of a bank can affect the quality of the loan portfolio with adverse consequences on the intermediary's overall business performance and, inevitably, on the local economy (Alessandrini et al., 2005). The reasons can largely be attributed to organizational and socio-cultural factors.

As regards the first aspect, it should be pointed out that a greater distance between headquarters and branches necessarily implies an organizational choice (trade-off) of the centralization/delegation autonomy of the branches. A distribution model based on mechanisms of delegation to the branches can support the application of efficient management decisions for the loan market at local level, but can expose the bank to considerable costs for controlling and monitoring the structure for potential agency head office/branch problems. On the contrary, organizational solutions based on a high centralization of lending decision-making powers, against the considerable cost savings in controlling/monitoring the structure, may encourage applying sub-optimal decisions to the needs of the different local situations, also lacking the possibility to codify the soft information (held by the branches), when assessing the quality of the customer loan. The empirical evidence demonstrates that the greater the functional distance, the higher the organizational diseconomies for the bank. In this context, Holmstrom (1982) and Palley (1997) highlight the effect that a large functional distance can have on the internal staff transfer dynamics and thus on the management of customer relations. More precisely, a bank with a greater functional distance can require, at least in theory, greater mobility for its employees and impair the quality of its relationship with its customers (Note 2).

Also to be highlighted is the fact that functional distance can also be understood as synonymous with the socio-cultural distance between the headquarters and the bank branches, and adversely affects the management of the lending relationship, particularly in the case of the centralization of autonomous lending decisions. In the absence of appropriate exchange and head office-branch information reporting mechanisms, a cultural remoteness from the market served may in fact increase information asymmetries on the competitive dynamics, and on local customers, for the entities deciding the credit lines and thus generate distortions in loan quality assessment (Degryse and Ongena, 2005). Although there are some simplifications in using mere functional distance to represent information, decision-making and relational diversity, such as organizational structures with different levels of knowledge and decision-making delegation locally, we formulate the following hypothesis:

Hp2: the loss given default rate positively depends on the organizational distance between the bank's headquarters and its branches (functional distance).

\section{Sample and data}

The sample used for the analysis is made up of Italian banks surveyed by the ABI Banking Data, in the four years 2005-2008; altogether, it comprises 2,697 observations (broken down into 684 banks in 2008, 689 in 2007, 672 in 2006 and 652 in 2005). Since lagged variables were used in the regressions (e.g. distressed loans $\mathrm{t}_{-1}$ ) or some variations with respect to the previous year, the observations used in the regression were reduced to 1,808 .

The representativeness of the sample over the four-year period is on average equal to $84.9 \%$ of the Italian banking system (the annual percentage is $85.5 \%$ in $2008,84.9 \%$ in 2007 and $86.25 \%$ in $2006,83.2 \%$ in 2005). The accounting data relating to the financial statements posted by the individual banks was drawn from the ABI Banking Data. 
The source of the data on the geographical location of the bank headquarters and branches is the Bank of Italy; this consists of a dataset of 150,407 branches (46,346 branches in 2008, 38,045 in 2007 and 33,486 in 2006, 32,530 in 2005), which also takes account of the effective opening period of a branch on the market during the observed years, and thus also valorizes the case of open/closed branches or those sold to other institutions (Note 3). The source of the data on the provincial distribution of the branches is also the Bank of Italy, while the macroeconomic data was drawn from the National Institute of Statistics (ISTAT). The outliers present in the database were treated with the winsoring technique, considering 1 percentile on both tails of the distribution sample.

\section{Analysis model and variables}

The research hypotheses formulated were tested by adopting a multivariate regression model (OLS) in the cross-section and time-series dimensions. It approximates the impact of the lending relationship approach on the loss given default rate, also taking into account the possible effects related to the specificity of the bank's business, the competitive dynamics of the local markets and the national macroeconomic trend (control variables).

The formulation of the OLS model is the following:

$L G D R_{i t}=\beta_{0}+\beta_{1} \Delta G D P_{i t}+\beta_{2} \Delta G D P_{i t-1}+\beta_{3} F-D I S T_{i t}+\beta_{4} T A_{i t}+\beta_{5} R O A_{i t-1}+\beta_{6} C R_{i t-1}+\beta_{7} S P E C_{i t}+\beta_{8} D R_{i t}+\beta_{9} C I_{i t}+$ $\beta_{10} H H I_{i t}+\beta_{11} M P_{i t}+\varepsilon_{i t}+u_{i}$

where $i$ identifies the individual bank belonging to the sample $(i=1,2,3, \ldots, 2,697) ; L G D R_{i t}$ is the $\mathrm{i}$-nth bank's loss given default rate; $t$ expresses the time variable $(t=2005 \ldots 2008) ; \beta_{1}, \beta_{2}, \ldots \beta_{11}$ are the parameters to be estimated. Also indicated in the model are the constant $\left(\beta_{0}\right)$ and the error terms $\left(\varepsilon_{i t} ; u_{t}\right)$. The panel regression approach adopted is of the random effect type; this hypothesis is subject to verification with the Hausman test shown in Table 4.

The set of variables adopted in the model can be grouped and distinguished based on the homogeneity of the analysis profile investigated in the four following macro-classes: relationship lending; banking business structure, macroeconomics and local market competition. The analytical description of each variable is illustrated in Table 1.

$<$ Table 1 about here $>$

In order to assess the LGDR, a proxy was constructed on the basis on the supervisory statistical return flow (Sironi and Zazzaro, 2008; Mattarocci and Gibilaro, 2009). The characteristics of the data collected and processed by ABI Banking Data have enabled an estimate of the LGDR as the ratio of the amount of bad debts that become worthless (the LGD entailed by the occurrence of a default) to the amount of loans that become distressed in the previous period. In formula:

$\mathrm{LGDR}_{\mathrm{t}}=\left(\mathrm{DLWO}_{\mathrm{t}} / \mathrm{DL}_{\mathrm{t}-1}\right)$

where:

$\mathrm{LGDR}_{\mathrm{t}}=$ Estimated value of the LGD;

$\mathrm{DLWO}_{\mathrm{t}}=$ Amount of distressed loans written off;

$\mathrm{DL}_{\mathrm{t}-1}=$ Amount of distressed loans.

As concerns the dependent variable (loss given default rate) it must be highlight that the general banking data base (i.e. Bankscope) does not allow the determination of this variable. This is an important original aspect of this work. Previous studies, in fact, provide a more general analysis of the problem of loan portfolio quality, based on the variables relating to non-performing loans. There are very few empirical analyses based on LGDR data (Mattarocci and Gibilaro, 2009; Dermine, Neto de Carvalho, 2006).

We consider, also, the variables used in literature as a proxy of the relationship lending technology. In previous studies (Alessandrini et al., 2009; Degryse and Ongena, 2005), the functional distance was adopted with this purpose and was calculated by considering the distance between the bank's head office and the provincial capital of the municipality in which the branches are located. In this work instead this variable was calculated by obtaining precise data of the real distance in kilometers, calculated as the distance between the postal code (ZIP CODE) of the bank's headquarters and the postal code of the municipalities in which the various branches are located (excluding the bank's liaison offices). Thereafter, each distance thus obtained, and pertaining to each ABI code, was weighted for the number of months each branch was open during the year. Analytically, the formula used in the calculation is the following:

$$
\text { F- } \text { Distance }_{\mathrm{i}}=\ln \left(1+\sum_{j=1}^{k}\left(\mid \text { ZIP CODE HeadQuarter }_{\mathrm{i}}-\text { ZIP CODE Branch }_{\mathrm{ij}} \mid \times \frac{m_{i j}}{12}\right)\right)
$$


where, for each year of observation, with reference to the i-th bank the sum of the distances between the head office's postal code and the $\mathrm{j}$-th branch's postal code is obtained, weighted by the branch's months of opening $(\mathrm{m}=1,2,3, \ldots$, 12).

Instead of the functional distance, we use the bank size, calculated as the natural logarithm of the bank's total assets as a proxy of the lending technology.

The first control variable adopted in the model is the level of collateralized loans. Basel 2 identifies as the key risk mitigation the collaterals obtained by the bank. Empirical studies (Jiménez and Saurina, 2004) verify the correlation between the amount of collaterals and the bank's organizational distance (distance between the bank's head office and the customer). The results show how banks featuring a shorter organizational distance are more likely to acquire guarantees.

A further control variable considered is the Return On Assets (ROA) of the previous year. Recent empirical studies (Godlewski, 2004; Boudriga et al., 2009) highlighted a negative relation between the bank's lagged ROA and the level of risk taking (non-performing loans). In particular, the authors maintain that a bank with satisfactory levels of profitability has a low propensity to assume risky choices that may penalize the profitability attained. We included in the regression the previous year's ROA to prevent model endogeneity problems. It is very likely, in fact, that the higher the LGDR the lower the ROA, as a result of the greater loan loss allowance.

A number of studies confirm that the bank's level of risk-taking, namely the amount of NPLs that it generates, depends on its Capital Ratio. The option-pricing model enables the demonstration of how a bank, in the absence of a capital requirement, tends towards excessive leverage and portfolio risk in order to maximize its shareholder value at the expense of deposit insurance (Benston et al., 1986; Furlong and Keeley, 1989; Keeley and Ferlong, 1990). The bank's capital ratio/risk-taking relation should be reversed: a higher level of capitalization reduces the probability that the bank yields to opportunistic behavior in its risk-taking decisions and adopts robust and balanced risk management models to reconcile the profitability expectations of shareholders and the depositor interests. In fact, the empirical results produced by Salas and Saurina (2002) on a sample of Spanish banks demonstrate that with the increase of the capital ratio, the amount of outstanding problem loans decreases. The theoretical foundations of the appropriateness of imposing minimum capitalization constraints on banks meet these conditions: a higher capital entails higher losses for the banks' shareholders in case of default, and hence lower risk-taking incentives (Repullo, 2002). We have included the previous year's Capital Ratio in the model to prevent any model endogeneity problems. Based on the supervisory regulations in fact (BIS, 2004), it is likely that the LGDR may affect the bank's Capital Ratio level.

The cost to income ratio is considered, consistently with Salas and Saurina (2002) and also Boudriga (2009). A high level of this indicator expresses the management's difficulty of benefiting from the branch network, damaging the quality of loans in the portfolio.

The literature suggests a relationship between the PD and LGD. Most of the empirical verifications made in this respect are conducted with reference to bond issues. Altman et al. (2005) demonstrate the existence of a negative relationship between the PD and the Recovery Rate, with reference to the issuance of corporate bonds for the US market in the 1982-2000 period, and the shorter 1987-2000 period.

The final firm-specific variable considered in literature is the degree of specialization of the bank's lending activity. The literature on this subject is vast and spreads across specific comparable conditions, such as, for example, the limits of the universal banking model, the bank diversification decisions by business, the bank income structure and portfolio diversification. The choice of a specialized banking business competitive model allows the bank, on the one hand, to effectively accumulate economies of experience and, on the other, to losing the economies of scope related to the appropriateness of implementing alternative strategies of the related diversification (Johnson, 1996; Rajan, 1996; Santos, 1998). In theoretical terms, diversification reduces the bank's level of risk-taking through a compensation of gains/losses mechanism, in relation to the overall product portfolio (Winton, 1999). Excessive competitive pressure on the realization of profits may in fact lead the bank to take more risks with the less accurate and efficient selection of investment projects worth funding. Therefore, a bank with a large share of non-interest revenue would be more selective and thus record fewer Non-Performing Loans. However, this issue is controversial. Hu et al. (2004), in fact, using a sample of 40 Taiwanese banks, demonstrate a direct correlation between revenue diversification and NPLs during the 1996-1999 period. Micco et al. (2004), using a sample of banks in developing countries, noted a significant and positive relationship between the presence of Non-Operating Revenues and Problem Loans in the 1995-2002 period.

The Herfindahl-Hirschman Index (HHI) represents the variable linked to the level of competition on local markets. The $\mathrm{HHI}$ is calculated as an average of the bank's concentration indexes in the provinces where it is present; in particular, in 
the absence of data on the intermediary's market share, an approximation based on the number of branches in the market (Coccorese, 2008) was carried out. The formula used is the following:

$$
\mathrm{HHI}_{\mathrm{i}}=\sum_{j=1}^{k} \frac{\left(\frac{\text { Bank branches }_{\mathrm{ij}}}{\text { Total system branches }_{\mathrm{j}}} \times 100\right)^{2}}{k}
$$

where the ratio between the i-th bank's branches in the j-th province and the total branches present in the same province represents the market share on the bank's provincial level.

The inclusion of this variable is suggested by the wide literature that studies the impact of the competitive dynamics of markets on the quality of the loan portfolio of banks (for recent studies see Udell, 2008; Jimez et al., 2010). Traditional theses associate greater risk-taking by the bank to a market with high competition (competition-fragility): the bank acting in a monopolistic or oligopolistic position, as competition grows, is driven to compensate the drop of margins by progressively increasing the level of risk taken, to avoid a progressive loss of market share; this idea appears to be supported by both theoretical (Marcus, 1984; Keeley, 1990; Broecker, 1990; Marquez, 2002) and empirical studies (Demsetz et al., 1996). The underlying logic links the reduction of market power to the decline of profitability and the consequent progressive shift towards the assumption of riskier positions. On this subject, however, recent empirical studies (Boyd et al., 2006; De Nicoló and Loukoianova, 2007) support the opposite view (competition-stability).

The model also includes a variable representing the bank's Market Power. This variable is calculated as the presence of branches of the bank not in the provincial capitals (i.e. municipalities) like Bongini et al. (2007). The calculation formula used is as follows:

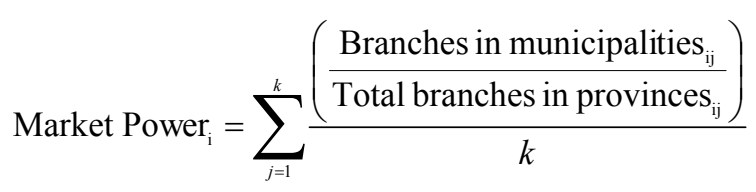

where $\mathrm{j}$ varies with the provinces in which the $\mathrm{i}$-th bank has a local presence and can reach the number of provinces equal to $\mathrm{k}$, the maximum of 103 (or local presence of the bank in all Italian provinces). The Market Power, unlike the HHI, better defines the effect of the local distribution of the branches. A bank can feature a low HHI (calculated at the provincial level), but find itself in a substantially oligopolistic situation, because its branches are located in municipalities where competition is lowest. The banks with a considerable market power (i.e. most branches are located in municipalities) operate in oligopolistic conditions and find it more convenient to invest in soft information (Petersen and Rajan, 1994).

However, among macroeconomic variables, the most frequently used in literature is the economic growth rate (GDP). Altman et al. (2005) demonstrate the existence of a positive relationship between recovery rate and GDP, with reference to the corporate bond market. Similar results are shown in Caselli et al. (2008), based on a portfolio of 11,649 contracts concluded on the Italian loan market.

\section{Results}

The descriptive statistics of the sample and the correlations between the variables adopted are contained, respectively, in Tables 2 and 3 .

$<$ Table 2 and 3 about here $>$

The results of the regressions are contained in Table 4 and follow a random effect approach, in line with the results of both tests. To avoid problems of multicollinearity three econometric models were built by selecting for each the regressors characterized by a lesser correlation.

\section{$<$ Table 4 about here $>$}

Having regard to the first test hypothesis (i.e. the existence of a positive relationship between the size of the bank and the LGDR - HP1), the Model 1 seems to confirm the existence of a significant relationship and with a positive coefficient. Consistently with other studies (Mattarocci and Gibilaro, 2009), the results show that large banks, characterized in theory by high organizational and business complexity, can have greater difficulty in transferring the customer's soft information (integrity of corporate ownership, skills and management capabilities, corporate networking opportunities, the entrepreneur's future strategic projects, etc.) to its organizational lending processes, to the reduction of 
the LGDR. The potential competitive disadvantage of large banks ensues, at least compared to the quality of the loan portfolio, with respect to smaller banks that are usually of a local and cooperative nature and are characterized by a more streamlined and efficient information management organizational structure, which ultimately leads to a lower default rate of the loan portfolio.

With regard to the second hypothesis (i.e. the existence of a positive relationship between the functional distance and the LGDR), Models 2 and 3 confirm the hypothesis because the result is significant and the sign of the coefficient is in line with the expectations. The geographical, cultural and organizational distance between the decision-making centre and the branches is examined in several theoretical contributions (Degryse and Ongena, 2005; Alessandrini et al., 2009) and can, indirectly, express a less intense lending relationship approach, characterized by a limited valorization of the soft information of customers within the organizational lending processes. The empirical evidence shows that as the functional distance increases, the intermediary's LGDR increases accordingly. This result is extremely important in the assessment of the impact of the consolidation process that characterized the Italian banking system in the years of observation (Bonaccorsi di Patti and Gobbi, 2007).

With regard to the control variables adopted in the models, we can observe how the relative amount of guarantees collected (collaterals) negatively affects the LDGR. This evidence is consistent with the supervisory regulations (BIS, 2004) and testifies to the importance of the collection of guarantees for risk mitigation purposes.

The regressions also highlight a positive relationship between the default rate and the LGDR, in contrast with an important part of the literature on credit risk management. In particular, Altman et al. (2005) demonstrate the existence of a positive relationship between default rate and recovery rate, while Jiménez and Saurina (2004) demonstrate how the loans with most guarantees (and, presumably, a lower LGDR) feature ex-post a higher PD. Account should be taken of an important element of discontinuity of our study, compared to the preceding literature. The procedure for determining the LGDR and PD of our sample is based on the accounting data relating to the banks' financial statements. Given the necessary recovery times the current year's LGDR is related to the recoveries of the loans that defaulted probably various years earlier. Instead, in the studies by Altman et al. (2005), there is a precise time correspondence between the counterparty rating and the recovery rate of the single loans. This difference can presumably explain the different sign obtained in the regression.

The other control variables relating to the banking business structure (ROA, capital ratio, specialization, cost to income ratio), in the proposed models, are not statistically significant.

As regards the macroeconomic variables and those relating to the local market competition, we can highlight how the GDP and LGD rate feature a negative and statistically significant relationship, consistently with the past studies (Caselli et al., 2008). The relationship appears to be statistically significant and more intense if reference is made to the previous year's GDP.

Regarding the control variables relating to the local market competition, the $\mathrm{HHI}$ is not statistically significant in the proposed models, while the Market Power is statistically significant and features a coefficient sign that is consistent with the literature. The location of the branches in the municipalities (with less competition), rather than in the provincial capital cities, improves the bank's recovery capability, also thanks to the establishment of tighter relationships and the banks' investments in soft information (Petersen and Rajan, 1994).

\section{Conclusions}

The aim of this study is to empirically verify the relationship that exists between the adoption of a relationship-based approach and Loss Given Default Rate, with respect to loans, based on the control variables relating to competitive dynamics and macroeconomic aspects. Using a sample of 2,697 observations, ascribable to the Italian banking system in the 2005-2008 period, the analysis highlights that larger banks, in theory characterized by greater organizational complexity, are also those that report a higher level of LGDR. This hypothesis is closely linked to the headquarters-branch distance. The results show a substantial correlation between this distance and the LGDR.

The bank's profitability decisions (ROA) appear not to affect the loan recovery rate, while an important role in the improvement of the LGDR is exercised by the collection of guarantees, consistently with the requirements of the Supervisory Authority.

The policy implications in this respect are the following: the size of the bank has been investigated in a large number of theoretical and empirical studies and has often been ascribed to a greater organizational complexity and a major use of analyses conducted on the basis of hard information. The larger banks appear to be more inefficient, also within the processes of recovery of deteriorated loans. This situation can be attributed and ascribed to the management of the relationship based solely on hard information, which generally reach the loan officer later compared to the unstructured 
information of the soft type. The time lag in the relationship management partially affects the recovery process. The functional distance too has the same impact on the LGDR, as a result of which the scattering of precious information within the organization impairs the efficiency of the recovery process.

The importance of a relationship also appears to be confirmed by the Market Power, because the banks with most branches located in the municipalities, rather than the provincial capitals, feature a lower level of LGDR. The cultural proximity and knowledge of the customer base generated in the smaller municipalities, rather than in the larger provincial capitals, helps, aids and assists the circulation and dissemination of important and significant soft information, with respect to the relationship between lenders and borrowers.

\section{Acknowledgments}

The authors thank Giuseppe Torluccio and Stefano Monferrà for comments and suggestions that helped to improve the paper. Even if this paper is the result of the shared research of two authors, paragraphs 1-3-4-6 can be attributed to Matteo Cotugno and paragraphs 2 and 5 can be attributed to Valeria Stefanelli.

\section{References}

Alessandrini, P., Croci, M., \& Zazzaro, A. (2005). The geography of banking power: the role of functional distance. $B N L$ Quarterly Review. 235, 129-167

Alessandrini, P., Presbitero, \& A.F., Zazzaro, A. (2009). Banks, Distances and Firms' Financing Constraints. Review of Finance. 13, 261-307, doi:10.1093/rof/rfn010, http://dx.doi.org/10.1093/rof/rfn010

Altman, E., Brady, B., Resti, A., \& Sironi, A. (2005). The link between default and recovery rates: theory empirical evidence and implications. Journal of Business. 78, 2203-2227, doi:10.1086/497044, http://dx.doi.org/10.1086/497044

Asarnow, E., Marker, J. (1995). Historical Performance of the U.S. Corporate Loan Market: 1988 - 1993, Commercial Lending Review. 13-32

Bank for International Settlement (BIS) (2006). International Convergence of Capital Measurement and Capital Standards: A Revised Framework - Comprehensive Version, [Online] Available: http://www.bis.org/publ/bcbs128.htm.

Beccalli, E., \& Bongini, P. (2009). Modelli di intermediazione delle banche europee e valutazione del mercato. Associazione per lo sviluppo degli Studi di Banca e Borsa e Università Cattolica del S. Cuore. Osservatorio Monetario, n. 1

Berger, A.N. \& Udell, G.F. (2002). Small business credit availability and relationship lending: The importance of bank organizational structure. Economic Journal. 112, F32-F53, doi:10.1111/1468-0297.00682, http://dx.doi.org/10.1111/1468-0297.00682

Berger, A.N., \& Frame, W.S. (2007). Small Business Credit Scoring and Credit Availability. Journal of Small Business Management. 45, 5-22, doi: 10.1111/j.1540-627X.2007.00195.x, http://dx.doi.org/10.1111/j.1540-627X.2007.00195.x

Berger, A.N., \& Udell, G.F. (1995). Relationship lending and lines of credit in small firm finance. Journal of Business. 68 , 351-382, doi:10.1086/296668, http://dx.doi.org/10.1086/296668

Berger, A.N., Cowan, A.M., \& Frame, W. S. (2010). The Surprising Use of Credit Scoring in Small Business Lending by Community Banks and the Attendant Effects on Credit Availability and Risk. Journal of Financial Services Research. Forthcoming, doi:10.1007/s10693-010-0088-1, http://dx.doi.org/10.1007/s10693-010-0088-1

Berger, A.N., Miller, N.H., Petersen, M.A., Rajan, R.G., \& Stein, J.C. (2005). Does function follow organizational form? Evidence from the lending practices of large and small banks. Journal of Financial Economics. 76, 237-269, doi:10.1016/j.jfineco.2004.06.003, http://dx.doi.org/10.1016/j.jfineco.2004.06.003

Berger, A.N., Rosen, R.J., \& Udell, G.F. (2007). Does market size structure affect competition? The case of small business lending. Journal of Banking and Finance. 31, 11-33, doi:10.1016/j.jbankfin.2005.10.010, http://dx.doi.org/10.1016/j.jbankfin.2005.10.010

Bonaccorsi di Patti, E. \& Gobbi, G. (2001). The changing structure of local credit markets: Are small business special?. Journal of Banking and Finance. 25, 2209-2237

Bonaccorsi di Patti, E., \& Gobbi, G. (2007). Winners or Losers? The Effects of Banking Consolidation on Corporate Borrowers. The Journal of Finance. 62, 669-695, doi:10.1111/j.1540-6261.2007.01220.x, http://dx.doi.org/10.1111/j.1540-6261.2007.01220.x 
Bongini, P., Di Battista, M.L., \& Nieri, L. (2009). Relationship banking: an old solution for the present crisis? Bancaria. 5, $2-20$

Bongini, P., Di Battista, M.L., \& Zavarrone, E. (2007). The Value of Relationship Lending: Small Banks in an Era of Consolidation. Economic Notes. 36, 209-230, doi:10.1111/j.1468-0300.2007.00184.x, http://dx.doi.org/10.1111/j.1468-0300.2007.00184.x

Boudriga, A., Taktak, N.B., \& Jellouli, S. (2009). Bank Specific, Business and Institutional Environment Determinants of Nonperforming Loans: Evidence from MENA Countries. ERF 16th annual conference, Cairo

Boyd, J.H., De Nicoló, G., \& Al Jalal, A. (2006). Bank risk taking and competition revisited: New theory and new evidence. International Monetary Fund. Working Paper 06/297

Brick, I.E., \& Palia, D. (2007). Evidence jointness in the terms of relationship lending. Journal of Financial Intermediation. 16, 452-476, doi:10.1016/j.jfi.2007.01.001, tp://dx.doi.org/10.1016/j.jfi.2007.01.001

Broecker, T. (1990). Creditworthiness Tests and Interbank Competition. Econometrica, 58, 429-452, doi:10.2307/2938210, http://dx.doi.org/10.2307/2938210

Carling, K. \& Lundberg, S. (2005). Asymmetric information and distance: an empirical assessment of geographical credit rationing. Journal of Economics and Business. 57, 39-59, doi:10.1016/j.jeconbus.2004.07.002, http://dx.doi.org/10.1016/j.jeconbus.2004.07.002

Carretta, A., \& Gibilaro, L. (2005). I fabbisogni informativi nel processo di rating interno per il portafoglio corporate delle banche: il caso della Loss Given Default, AA.VV. La riconfigurazione dei processi decisionali nel quadro evolutivo della competizione, 27 Convegno AIDEA, Giappichelli, Turin.

Caselli, S., Gatti, S., \& Querci F. (2008). The Sensitivity of the Loss Given Default Rate to Systematic Risk: New Empirical Evidence on Bank Loans. Journal of Financial Services Research. 34, 1-34, doi:10.1007/s10693-008-0033-8, http://dx.doi.org/10.1007/s10693-008-0033-8

Coccorese, P. (2008). Bank competition and regional differences. Economics Letters. 101, 13-16, doi:10.1016/j.econlet.2008.03.019, http://dx.doi.org/10.1016/j.econlet.2008.03.019

Cole, R.A. (1998). The role of relationship to availability of credit. Journal of Banking and Finance. 22, 959-977, doi:10.1016/S0378-4266(98)00007-7, http://dx.doi.org/10.1016/S0378-4266(98)00007-7

De Laurentis G., \& Riani M. (2005). Estimating LGD in the leasing industry: empirical evidence from a multivariate model. Altman, E., Resti, A., Sironi, A. (eds). Recovery risk: the next challenge in credit risk management. Risk Books, London

Degryse, H.A., \& Ongena, S. (2005). Distance, lending relationship, and competition. The Journal of Finance, 60, 231-266, doi:10.1111/j.1540-6261.2005.00729.x, http://dx.doi.org/10.1111/j.1540-6261.2005.00729.x

Degryse, H.A., Cerqueiro, G.M., \& Ongena, S. (2007). Distance, Bank Organizational Structure and Credit, Discussion Paper 018. Tilburg University, Tilburg Law and Economic Center

Demsetz, R.S., Saidenberg, M.R., \& Strahan, P.E. (1996). Banks with something to lose: The disciplinary role of franchise value. FRBNY Economic Policy Review 1-14

Dermine, J., \& Carvalho, C.N. (2006). Bank loan Loss Given Default: a case study. Journal of Banking and Finance, 30 1219-1243, doi:10.1016/j.jbankfin.2005.05.005, http://dx.doi.org/10.1016/j.jbankfin.2005.05.005

Dewatripont, M., \& Roland, G. (2000). Soft Budget Constraints, Transition, and Industrial Change. Journal of Institutional and Theoretical Economics. 156, 245-256

Deyoung, R., Hunter, R.W., \& Udell G.F. (2004). Past, Present and Probable Future for Community Banks. Journal of Financial Services Research. 25, 85-133, DOI: 10.1023/B:FINA.0000020656.65653.79, http://dx.doi.org/10.1023/B:FINA.0000020656.65653.79

Elsas, R. (2005). Empirical determinants of relationship lending, Journal of Financial Intermediation, vol.14, pp.32-57. doi:10.1016/j.jfi.2003.11.004, http://dx.doi.org/10.1016/j.jfi.2003.11.004

Ferri, G., \& Messori, M. (2000), Bank firm relationships and allocative efficiency in North-Eastern and Central Italy and in the South. Journal of Banking and Finance. 24, 1067-1095, doi:10.1016/S0378-4266(99)00118-1, http://dx.doi.org/10.1016/S0378-4266(99)00118-1 
Gibilaro, L., \& Mattarocci, G. (2007). The selection of the discount rate in estimating the Loss Given Default, Global Journal of Business Research. 1, 15-35

Gobbi, G., \& Bofondi, M. (2006). Informational Barriers to Entry into Credit Markets. Review of Finance. 10, 39-67, doi:10.1007/s10679-006-6978-2, http://dx.doi.org/10.1007/s10679-006-6978-2

Godlewski, C.J. (2004). Bank capital and credit risk taking in emerging market economies. Journal of Banking Regulation. $6,128-145$

Holmstrom, B., \& Ricart-i-Costa J. (1986). Managerial incentives and capital management. Quarterly Journal of Economics. 101, 835-60, doi:10.2307/1884180, http://dx.doi.org/10.2307/1884180

Jiménez, G., \& Saurina, J. (2004). Collateral, type of lender and relationship banking as determinants of credit risk. Journal of Banking and Finance. 28, 2191-2212

Jiménez, G., Lopez, J.A., \& Saurina, J. (2010). How does competition impact bank risk-taking?. Documentos de Trabajo $n$. 1005. Banco De España

Keeton, W., \& Morris, C.S. (1987). Why Do Banks' Loan Losses Differ?. Federal Reserve Bank of Kansas City. Economic Review. May, 3-21

Keeton, W.R. (1999). Does Faster Loan Growth Lead to Higher Loan Losses?. Federal Reserve Bank of Kansas City. Economic Review. Second Quarter

Kornai, J., Maskin, E., \& Roland G. (2003). Understanding the Soft Budget Constraint. Journal of Economic Literature. XLI, 1095-1136, doi:10.1257/002205103771799999, http://dx.doi.org/10.1257/002205103771799999

Longhofer, S.D., \& Santos, J.A.C. (1999). The importance of bank seniority for relationship lending. Federal Reserve Bank

Marcus, A.J. (1984). Deregulation and bank financial policy. Journal of Banking and Finance. 8, 557-565, doi:10.1016/S0378-4266(84)80046-1, http://dx.doi.org/10.1016/S0378-4266(84)80046-1

Marquez, R. (2002). Competition, adverse selection, and information dispersion in the banking industry. Review of Financial Studies. 15, 901-926, doi:10.1093/rfs/15.3.901, http://dx.doi.org/10.1093/rfs/15.3.901

Mattarocci, G., \& Gibilaro, L. (2009). Characteristics of the Recovery Process for Small Financial Intermediaries: the Case of Italian Cooperative Banks. Academy of Banking Studies Journal. 8, 75-94

McNulty, J.E, Akhigbe, A.O., \& Verbrugge J.A. (2001). Small bank loan quality in a deregulated environment: the information advantage hypothesis. Journal of Economics and Business. 53, 325-339, doi:10.1016/S0148-6195(00)00050-3, http://dx.doi.org/10.1016/S0148-6195(00)00050-3

Micco, A., Panizza, U., Yañez, M. (2004), Bank Ownership and Performance. Inter-American Development Bank. Working paper, no. 518

Nakamura, L. (1993a), Commercial Bank Information: Implications for the Structure of Banking. Klausner, M.D., \& White, L.J. editors. Structural Change in Banking. Homewood. Illinois: Business One Irwin.

Nakamura, L. (1993b). Recent Research in Commercial Banking: Information and Lending, Financial Markets, Institutions and Instruments, n. 2, 73-88

Palley, T.L. (1997). Managerial turnover and the theory of short-termism. Journal of Economic Behavior and Organization. 32, 547-57, doi:10.1016/S0167-2681(97)00012-7, http://dx.doi.org/10.1016/S0167-2681(97)00012-7

Petersen M.A., Rajan, R.G. (2002), Does distance still matter? The information revolution in small business lending, The Journal of Finance, vol. 57, pp. 2533-2570, doi:10.1111/1540-6261.00505, http://dx.doi.org/10.1111/1540-6261.00505

Petersen, M.A., \& Rajan, R.G. (1994). The benefits of lending relationships: Evidence from small business data. The Journal of Finance. 49, 3-37, doi:10.2307/2329133, http://dx.doi.org/10.2307/2329133

Petersen, M.A., \& Rajan, R.G. (1995). The effect of credit market competition on lending relationships. The Quarterly Journal of Economics. 110, 407-443, doi:10.2307/2118445, http://dx.doi.org/10.2307/2118445

Presbiterio, A.F., \& Zazzaro, A. (2010). Competition and Relationship Lending: Friends or Foes? Journal of Financial Intermediation. Forthcoming

Repullo, R. (2002). Capital requirements, market power, and risk-taking in banking. Journal of Financial Intermediation. $13,156-182$ 
Salas, V., \& Saurina, J. (2002). Credit Risk in Two Institutional Regimes: Spanish Commercial and Savings Banks. Journal of Financial Services Research. 22, 203-224, doi:10.1023/A:1019781109676, http://dx.doi.org/10.1023/A:1019781109676

Schuermann, T. (2004), What Do We Know About Loss Given Default? Working Paper. Wharton Financial Institutions Center, [Online] Available: http://fic.wharton.upenn.edu/fic/papers/04/0401.pdf.

Scott, J.A. (2004). Small business and the value of community financial institutions. Journal of Financial Services Research. 25, 207-230, doi:10.1023/B:FINA.0000020661.30763.fe, http://dx.doi.org/10.1023/B:FINA.0000020661.30763.fe

Sharpe, S. A. (1990). Asymmetric information, bank lending, and implicit contracts: A stylized model of customer relationships. The Journal of Finance. 45, 1069-1087, doi:10.2307/2328715, http://dx.doi.org/10.2307/2328715

Sironi, A., \& Zazzara, C. (2003). The Basel Committee proposals for a new capital accord: implication for Italian banks. Review of Financial Economics, 12 99-126, doi:10.1016/S1058-3300(03)00009-0(03)00009-0, http://dx.doi.org/10.1016/S1058-3300(03)00009-0

Stefanelli, V., \& Cotugno, M. (2011). An Empirical Analysis on Board Monitoring Role and Loan Portfolio Quality Measurement in Banks. Academy of Banking Studies Journal (forthcoming)

Stein, J.C. (2002). Information production and capital allocation: Decentralized versus hierarchical firms. The Journal of Finance. 57, 1891-1921, doi: 10.1111/0022-1082.00483, http://dx.doi.org/10.1111/0022-1082.00483

Taketa, K., \& Udell, F.G. (2007). Lending Channels and Financial Shocks: The Case of Small and Medium-Sized Enterprise Trade Credit and the Japanese Banking Crisis. Monetary and Economic Studies. Institute for Monetary and Economic Studies. Bank of Japan, 25, 1-44

Udell, G.F. (1989). Loan quality, commercial loan review and loan officer contracting. Journal of Banking and Finance. 13, 367-382, doi:10.1016/0378-4266(89)90048-4, http://dx.doi.org/10.1016/0378-4266(89)90048-4

Zazzaro, A. (2006), La scomparsa dei centri decisionali dal sistema bancario meridionale. Rivista di Politica Economica. 96, 31-60

\section{Notes}

Note 1. The contrast between the two intermediation lending models, relationship vs. transactional, according to some authors is a simplification of reality, since different lending technologies can be identified intended as the "unique combination of primary information source, screening and underwriting policies/procedures, loan contract structure and monitoring strategies/mechanisms" (Taketa and Udell, 2007; Udell, 2008).

Note 2. For example, think of the effects on the credit rating process linked to the possible loss of soft information accumulated over time and the "property" of an employee having transferred to another branch and, further, to the potential opportunistic behaviors of the same subject in the branch, dictated by the "myopic" and short term vision of the business relationship with the customers served.

Note 3. In view of the cases of the sale of branches to other institutions during the course of the year, the number of branches of the sample does not coincide with the data reported in the Bank of Italy's Annual Report Glossary. 
Table 1. Definition of variables

\begin{tabular}{|c|c|c|}
\hline Variables & Abbrev. & Measure \\
\hline \multicolumn{3}{|l|}{ Dependent Variable } \\
\hline Loss Given Default Rate $_{t}$ & LGDR & Distressed loans written off $\mathrm{t}_{\mathrm{t}} /$ Distressed loans $_{\mathrm{t}-1}$ \\
\hline \multicolumn{3}{|l|}{ Relationship lending } \\
\hline F-Distance $_{t}$ & F-DIST & $\begin{array}{l}\text { Natural logarithm of sum of Distance between } \\
\text { ZIP Code of Headquarter of bank and ZIP Code of } \\
\text { branches }\end{array}$ \\
\hline Bank size $_{t}$ & TA & Ln(Total Assets $\left.{ }_{t}\right)$ \\
\hline \multicolumn{3}{|l|}{ Banking business structure } \\
\hline Collateral $_{\mathrm{t}}$ & COLL & Collateralized loans $\mathrm{t}_{\mathrm{t}} /$ Gross Loans $_{\mathrm{t}}$ \\
\hline $\mathrm{ROA}_{\mathrm{t}}$ & ROA & Before Tax Profit ${ }_{t} /$ Total Assets $_{t}$ \\
\hline Capital Ratio $_{t}$ & CR & Equity $_{\mathrm{t}} /$ Total Assets $_{\mathrm{t}}$ \\
\hline Default Rate $_{t}$ & DR & $\begin{array}{l}\text { New Non Performing Loans } /\left(\text { Gross Loans }_{t-1}-\right. \\
\left.\text { Non Performing Loans } \mathrm{t}_{\mathrm{t}-1}\right)\end{array}$ \\
\hline Specialization $_{t}$ & SPEC & Loans $_{\mathrm{t}} /$ Total Assets $_{\mathrm{t}}$ \\
\hline Cost to Income $_{t}$ & $\mathrm{CI}$ & Operational Costs $_{\mathrm{t}} /$ Intermediation Margin $_{\mathrm{t}}$ \\
\hline \multicolumn{3}{|l|}{ Macroeconomics and Local Market competition } \\
\hline Herfindahl-Hirschman Index $_{t}$ & HHI & $\begin{array}{l}\text { Index of concentration of branches in the bank's } \\
\text { provinces of relevance }\end{array}$ \\
\hline \multicolumn{3}{|l|}{${\text { Market } \text { Power }_{t}}$} \\
\hline$\Delta \mathrm{GDP}_{\mathrm{t}}$ & $\Delta \mathrm{GDP}_{\mathrm{t}}$ & GDP variation \\
\hline
\end{tabular}

Notes: Net loans = customer loans; Gross loans $=$ customer loans + individual loan loss allowance + portfolio loan loss allowance;

Table 2. Univariate descriptive statistics, Italian Banks (2005-2008).

\begin{tabular}{|l|c|c|c|c|c|c|}
\hline Variables & N. Obs & Mean & SD & Min & Median & Max \\
\hline Loan portfolio quality & 1808 & 0.109 & 0.158 & 0.000 & 0.047 & 0.837 \\
\hline Loss Given Default & 2697 & 4.833 & 2.806 & 0.000 & 4.735 & 13.576 \\
\hline Relationship lending variables & 2697 & 13.035 & 1.779 & 8.499 & 12.743 & 19.878 \\
\hline F-Distance & 2697 & 0.639 & 0.197 & 0.003 & 0.689 & 0.947 \\
\hline Bank Size & 2697 & 0.674 & 0.216 & 0.000 & 0.729 & 0.926 \\
\hline Banking business structure variables \\
\hline Specialization & 2697 & 0.122 & 0.070 & 0.026 & 0.107 & 0.554 \\
\hline Collaterals & 2697 & 0.665 & 0.273 & 0.181 & 0.626 & 2.426 \\
\hline Capital Ratio & 2697 & 0.009 & 0.010 & -0.042 & 0.010 & 0.039 \\
\hline Cost to income & 2697 & 908.957 & 281.609 & 355.107 & 879.487 & 1992.649 \\
\hline ROA & 2697 & 0.742 & 0.335 & 0.000 & 0.875 & 1.000 \\
\hline Local competition and macroeconomics & 2697 & 0.008 & 0.012 & -0.010 & 0.016 & 0.020 \\
\hline HHI
\end{tabular}

All variables are winsorized at the bottom and top $1 \%$ levels. 
Table 3. Bivariate Descriptive Statistic (2005-2008). Correlation between some variables, case wise.

\begin{tabular}{|c|c|c|c|c|c|c|c|c|c|c|c|c|c|}
\hline & & 1 & 2 & 3 & 4 & 5 & 6 & 7 & 8 & 9 & 10 & 11 & 12 \\
\hline 1 & LGD & 1.000 & & & & & & & & & & & \\
\hline \multirow[t]{2}{*}{2} & GDP & -0.022 & 1.000 & & & & & & & & & & \\
\hline & & $(0.357)$ & & & & & & & & & & & \\
\hline \multirow[t]{2}{*}{3} & F-Distance & $0.169 *$ & 0.002 & 1.000 & & & & & & & & & \\
\hline & & $(0.000)$ & $(0.937)$ & & & & & & & & & & \\
\hline \multirow[t]{2}{*}{4} & TA & $0.221 *$ & -0.026 & $0.795 *$ & 1.000 & & & & & & & & \\
\hline & & $(0.000)$ & $(0.264)$ & $(0.000)$ & & & & & & & & & \\
\hline \multirow[t]{2}{*}{5} & $\mathrm{ROA}$ & -0.004 & $0.219^{*}$ & $0.044 *$ & -0.019 & 1.000 & & & & & & & \\
\hline & & $(0.862)$ & $(0.000)$ & $(0.062)$ & $(0.431)$ & & & & & & & & \\
\hline \multirow[t]{2}{*}{6} & Specialization & $0.060^{*}$ & -0.024 & $0.214^{*}$ & $0.134^{*}$ & 0.004 & 1.000 & & & & & & \\
\hline & & $(0.010)$ & $(0.303)$ & $(0.000)$ & $(0.000)$ & $(0.855)$ & & & & & & & \\
\hline \multirow[t]{2}{*}{7} & Collaterals & $-0.132 *$ & -0.016 & $-0.154 *$ & $-0.324 *$ & $0.146^{*}$ & $0.055^{*}$ & 1.000 & & & & & \\
\hline & & $(0.000)$ & $(0.487)$ & $(0.000)$ & $(0.000)$ & $(0.000)$ & $(0.020)$ & & & & & & \\
\hline \multirow[t]{2}{*}{8} & Capital Ratio & $-0.088^{*}$ & 0.037 & $-0.422 *$ & $-0.391 *$ & $0.284 *$ & $-0.156^{*}$ & $0.116^{*}$ & 1.000 & & & & \\
\hline & & $(0.000)$ & $(0.111)$ & $(0.000)$ & $(0.000)$ & $(0.000)$ & $(0.000)$ & $(0.000)$ & & & & & \\
\hline \multirow[t]{2}{*}{9} & Default Rate & 0.027 & $-0.066^{*}$ & 0.028 & -0.014 & $-0.283 *$ & $-0.128^{*}$ & $-0.066^{*}$ & -0.016 & 1.000 & & & \\
\hline & & $(0.257)$ & $(0.005)$ & $(0.241)$ & $(0.549)$ & $(0.000)$ & $(0.000)$ & $(0.005)$ & $(0.498)$ & & & & \\
\hline \multirow[t]{2}{*}{10} & Cost Income & $-0.059 *$ & $-0.097 *$ & $-0.090 *$ & $-0.242 *$ & -0.590 * & $-0.126^{*}$ & 0.003 & $-0.081 *$ & $0.169 *$ & 1.000 & & \\
\hline & & $(0.013)$ & $(0.000)$ & $(0.000)$ & $(0.000)$ & $(0.000)$ & $(0.000)$ & $(0.889)$ & $(0.001)$ & $(0.000)$ & & & \\
\hline \multirow[t]{2}{*}{11} & Market Power & $-0.142 *$ & $0.043^{*}$ & $-0.256^{*}$ & $-0.478 *$ & $0.230^{*}$ & $0.085^{*}$ & $0.357^{*}$ & $0.218^{*}$ & $-0.080^{*}$ & -0.015 & 1.000 & \\
\hline & & $(0.000)$ & $(0.065)$ & $(0.000)$ & $(0.000)$ & $(0.000)$ & $(0.000)$ & $(0.000)$ & $(0.000)$ & $(0.001)$ & $(0.530)$ & & \\
\hline \multirow[t]{2}{*}{12} & HHI Medio & -0.002 & -0.052 & $0.203 *$ & $0.090^{*}$ & 0.029 & $-0.087 *$ & $-0.048^{*}$ & $-0.066^{*}$ & $0.164 *$ & $0.057^{*}$ & $-0.072 *$ & 1.000 \\
\hline & & $(0.944)$ & $(0.028)$ & $(0.000)$ & $(0.000)$ & $(0.226)$ & $(0.000)$ & $(0.041)$ & $(0.005)$ & $(0.000)$ & $(0.016)$ & $(0.002)$ & \\
\hline
\end{tabular}

* Significance level at least $10 \%$

In bold character: variables that have high correlation and have been put in different regression model. 
Table 4. Dependent variable Loss Given Default; Cross section and time series regression with Random Effect

\begin{tabular}{|c|c|c|c|}
\hline & Model 1 & Model 2 & Model 3 \\
\hline \multirow[t]{2}{*}{$\Delta \mathrm{GDP}_{\mathrm{t}}$} & $-0.489 * *$ & $-0.476^{* *}$ & $-0.557 * *$ \\
\hline & $(2.08)$ & $(1.97)$ & $(2.37)$ \\
\hline \multirow[t]{2}{*}{$\Delta \mathrm{GDP}_{\mathrm{t}-1}$} & $-1.346^{* *}$ & $-1.385 * *$ & $-1.356^{* *}$ \\
\hline & $(2.42)$ & $(2.49)$ & $(2.44)$ \\
\hline \multirow[t]{2}{*}{ Specialization $_{\mathrm{t}}$} & 0.0294 & 0.0330 & 0.0277 \\
\hline & $(1.08)$ & $(1.22)$ & $(1.06)$ \\
\hline \multirow[t]{2}{*}{ Collaterals $_{\mathrm{t}}$} & $-0.0555^{* *}$ & $-0.0573 * *$ & $-0.0469 * *$ \\
\hline & $(-2.48)$ & $(-2.55)$ & $(-2.12)$ \\
\hline \multirow[t]{2}{*}{ Default Rate $_{t}$} & $0.599 * *$ & $0.615^{* *}$ & $0.673 * *$ \\
\hline & $(2.02)$ & $(2.00)$ & $(2.28)$ \\
\hline \multirow[t]{2}{*}{$\mathrm{HHI}_{\mathrm{t}}$} & -0.0000178 & -0.0000195 & -0.0000127 \\
\hline & $(-1.37)$ & $(-1.50)$ & $(-1.00)$ \\
\hline \multirow[t]{2}{*}{ Market Power $_{t}$} & $-0.0536 * * *$ & $-0.0557 * * *$ & \\
\hline & $(-3.34)$ & $(-3.43)$ & \\
\hline \multirow[t]{2}{*}{ F-Distance $_{t}$} & $0.00673 * * *$ & $0.00668^{* * *}$ & \\
\hline & $(3.53)$ & $(3.44)$ & \\
\hline \multirow[t]{2}{*}{${\text { Cost } / \text { Income }_{t}}_{\text {. }}$} & -0.0382 & & -0.00543 \\
\hline & $(-1.49)$ & & $(-0.21)$ \\
\hline \multirow[t]{2}{*}{ Capital Ratio $_{t-1}$} & -0.0246 & -0.0384 & \\
\hline & $(-0.24)$ & $(-0.37)$ & \\
\hline \multirow[t]{2}{*}{$\mathrm{ROA}_{\mathrm{t}-1}$} & & 0.526 & \\
\hline & & $(0.89)$ & \\
\hline \multirow[t]{2}{*}{ Bank Size $_{t}$} & & & $0.0182 * * *$ \\
\hline & & & $(6.44)$ \\
\hline \multirow[t]{2}{*}{ Constant } & $0.147 * * *$ & $0.121 * * *$ & $-0.135 * *$ \\
\hline & $(3.93)$ & $(3.77)$ & $(-2.51)$ \\
\hline N. Obs & 1808 & 1808 & 1808 \\
\hline N. Group & 666 & 666 & 666 \\
\hline $\mathrm{R}^{2}$ Overall & 0.0523 & 0.0513 & 0.0585 \\
\hline Chi2 & $69.93 * * *$ & $68.55 * * *$ & $78.67 * * *$ \\
\hline Hausman test & 10.71 & 10.81 & 11.82 \\
\hline
\end{tabular}

Heteroskedasticity-robust t-stat is in brackets. The symbol *** indicates a significance level of $1 \%$ or less; ** between 1 and $5 \%$; $*$ between 5 and $10 \%$. 